\title{
Downregulation of neurotrophic factors in the brain of a mouse model of Gaucher disease; implications for neuronal loss in Gaucher disease
}

\author{
Eun Young Kim ${ }^{1}$, Young Bin Hong ${ }^{1}$, \\ Sang Hee Go ${ }^{1}$, Beobyi $\mathrm{Lee}^{2}$ and \\ Sung-Chul Jung ${ }^{3,4}$
}

${ }^{1}$ Department of Biomedical Sciences

National Institute of Health

Seoul 122-701, Korea

${ }^{2}$ Department of Anatomy

College of Medicine, Konkuk University

Chungju 380-701, Korea

${ }^{3}$ Department of Biochemistry

College of Medicine, Ewha Womans University

Seoul 158-710, Korea

${ }^{4}$ Corresponding author: Tel, 82-2-2650-5725;

Fax, 82-2-2652-7842; E-mail, jungsc@ewha.ac.kr

Accepted 22 May 2006

Abbreviations: BDNF, brain-derived neurotrophic factor; ERK, extracellular signal-regulated kinase; GC, glucocerebrosidase; MAPK, mitogen-activated protein kinase; NGF, nerve growth factor; NT, neurotrophin; Trk, tyrosine kinase receptor

\footnotetext{
Abstract

Gaucher disease is a glycosphingolipid storage disease caused by deficiency of glucocerebrosidase, resulting in the accumulation of glucosylceramide in lysosomes. The neuronopathic forms of this disease are associated with neuronal loss and neurodegeneration. However, the pathophysiological mechanisms leading to prenatal and neonatal death remain uncharacterized. To in vestigate brain dysfunction in Gaucher disease, we studied the effects of neurotrophic factors during development in a mouse model of Gaucher disease. The expression of brain-derived neurotrophic factor and nerve growth factor was reduced in the cerebral cortex, brainstem, and cerebellum of Gaucher mice, compared with that in wild-type mice. Extracellular signal-regulated kinase (ERK) 1/2 expression was downregulated in neurons from Gaucher mice and correlated with a decreased number of neurons. These results suggest that a reduction in neurotrophic factors could be involved in neuronal loss in Gaucher disease.
}

Keywords: brain; brain-derived neurotrophic factor; Gaucher disease; glucosylceramidase; nerve growth factor; neurons

\section{Introduction}

Gaucher disease (OMIM 230800, 230900, 231000) is a lysosomal sphingolipid storage disorder caused by a deficiency of glucocerebrosidase (GC; glucosylceramidase, D-glucosyl- $N$-acylsphingosine glucohydrolase, EC 3.2.1.45) (Brady et al., 1965). This disease is characterized by the accumulation of glucosylceramide in macrophages and macrophagederived cells in various tissues (Brady et al., 1966; Beutler and Grabowski, 2001). Patients with Gaucher disease are classified into three clinical phenotypes: non-neuronopathic (type I), acute neuronopathic (type II), and chronic neuronopathic (type III). Patients with Gaucher disease type I usually present with hepatosplenomegaly and bone disease, but do not have central nervous system symptoms. Patients with Gaucher disease type II or type III have additional neurological symptoms, which may lead to neurodegeneration in infancy or take an intermediate course (Conradi et al., 1984; Brady et al., 1993). The characteristics of the neuronopathic forms include extensive neuronal loss in the anterior horn, basal ganglia, pons, medulla, cerebellum, and hypothalamus, and an increased concentration of glucosylceramide and glucosylsphingosine in the cerebral cortex and cerebellum (Grafe et al., 1988; Orvisky et al., 2000; Wong et al., 2004).

A mouse model of Gaucher disease has been created by targeted disruption of the GC gene (Tybulewicz et al., 1992). These Gaucher mice are deficient in GC activity, show glucosylceramide accumulation in the bone marrow, liver, spleen, and brain, and diffuse storage of glucosylceramide in the microglial cells, brainstem neurons, and spinal cord neurons. They die within a day of birth, primarily from a skin defect (Tybulewicz et al., 1992).

We recently showed that $\mathrm{Bcl}-2$ is downregulated in the brains of fetal Gaucher mice, and we detected neural cell apoptosis (TUNEL-positive cells) in the brains of Gaucher mice (Hong et al., 2004). However, the pathophysiological mechanisms that lead to the neurological symptoms of this disease have not been clearly defined. In this study, we 
investigated the effects of neurotrophic factors in Gaucher disease. Neurotrophic factors play an important role in neuronal survival, differentiation, and plasticity (Dudek et al., 1997; Miller et al., 1997; Heese et al., 2004). Previous studies have shown that deficiencies in neurotrophic factors, including brain-derived neurotrophic factor (BDNF), nerve growth factor (NGF), transforming growth factor $\beta$ (TGF- $\beta$ ), and ciliary neurotrophic growth factor (CNTF), result in massive cell death and neurodegeneration in the central nervous systems of mutant mice (Sendtner et al., 1992; Crowley et al., 1994; Ernfors et al., 1994; Letterio, 2000). We compared the roles of neurotrophic factors throughout embryonic and postnatal development and analyzed the expression of neurotrophic factors in wild-type mice and the mouse model of Gaucher disease.

\section{Materials and Methods}

\section{Mouse model of Gaucher disease}

The GC-deficient model mouse (C57BL/6J-Gba ${ }^{\mathrm{tm} 1 \mathrm{Nsb}}$ ) was obtained from the Jackson Laboratory (Bar Harbor, ME). In this homozygous mouse model of Gaucher disease, $<4 \%$ of normal GC activity is expressed, glucosylceramide is stored in the lysosomes of cells, and the mice die within one day of birth (Tybulewicz et al., 1992). All animals were housed at the Korea National Institute of Health, and were treated according to the National Institutes of Health guidelines for animal care.

\section{Neuronal cultures}

Neurons from Gaucher mice and their wild-type littermates were cultured. Briefly, the brains of wild-type and Gaucher mice at embryonic days 17.5 (E17.5) and 19.5 (E19.5) and postnatal day 1 (P1) were separated into cerebral cortex, brainstem, and cerebellar regions. The cells of the dissected regions were dissociated by trypsinization $(0.25 \% \mathrm{w} / \mathrm{v})$ for 15 $\min$ at $37^{\circ} \mathrm{C}$, washed in $\mathrm{Mg}^{2+} / \mathrm{Ca}^{2+}$-free Hanks' balanced salt solution (Life Technologies, Grand Island, NY), and then further dissociated by repeated passages through a constricted Pasteur pipette. The cells were resuspended in Neurobasal ${ }^{\mathrm{TM}}$ medium (Life Technologies) containing B27 supplements (Life Technologies) and plated at a density of $1 \times$ $10^{5}$ cells/well in six-well plates that had been precoated with poly-l-lysine $(1 \mathrm{mg} / \mathrm{ml})$. All cells were analyzed after 10-14 days in vitro (DIV). Glial proliferation was prevented by the addition to the medium of cytosine $\beta$-D-arabinoside $(5 \mu \mathrm{M})$ on day 2 of culture.

\section{Reverse transcription-polymerase chain reaction (RT-PCR)}

Total RNA was isolated from the different brain regions (cerebral cortex, brainstem, and cerebellar regions) at $E 17.5, E 19.5$, and $P 1$, and from the neuronal cells of wild-type and Gaucher mice collected at E17.5 and P1, using an RNeasy Mini Kit (Qiagen Inc., Valencia, CA). cDNA was transcribed using oligo dT primer and MMLV reverse transcriptase (Promega, Madison, WI), according to the instructions of the manufacturer. Aliquots of the RT products were amplified by PCR using 20 cycles of $94^{\circ} \mathrm{C}$ for $45 \mathrm{~s}, 60^{\circ} \mathrm{C}$ for $30 \mathrm{~s}$, and $72^{\circ} \mathrm{C}$ for $30 \mathrm{~s}$. The PCRs were performed in reaction volumes of $25 \mu \mathrm{l}$, which included $2 \mu$ of RT product as the template, 1 $\times$ reaction buffer, $1 \mathrm{U}$ of Ex Taq DNA polymerase (TaKaRa, Japan), and 20 pmol of each primer. Primer sequences were as follows: $\beta$-actin, 5'-CCCACACTGTGCCCATCTAC-3' and 5'-AGTACTTGCGCTCAGGAGGA-3'; BDNF, 5'-TGGCTGACACTTTTGAGCAC-3' and 5'-TCAGTTGGCCTTTGGATACC3'; and NGF, 5'-CTGTGGACCCCAGACTGTTT-3' and 5'-GCACCCACTCTCAACAGGAT-3'. The PCR products were analyzed on $1 \%$ agarose gels.

\section{BDNF immunohistochemistry}

Wild-type and Gaucher mice at P1 were perfused with $1.5 \mathrm{ml}$ of saline, then with fixative containing $4 \%$ paraformaldehyde in $0.01 \mathrm{M}$ phosphate-buffered saline (PBS; $p H$ 7.4). The brains were removed and stored in the same fixative for $4 \mathrm{~h}$ and in $30 \%$ sucrose cryoprotectant overnight. A series of 40-50$\mu \mathrm{m}$ cryostat sections of whole brains were cut and collected in the wells of a tissue culture plate. Immunohistochemistry was performed using the conventional peroxidase-antiperoxidase (PAP) technique of Sternberger and Sternberger (1986). Briefly, sections were incubated in $0.5 \% \quad \mathrm{H}_{2} \mathrm{O}_{2}$ in Trisbuffered saline (TBS) for $20 \mathrm{~min}$, blocked in $10 \%$ normal goat serum for $1 \mathrm{~h}$, and then incubated with rabbit anti-BDNF antibody (Chemicon, Temecula, $\mathrm{CA}$ ) at a dilution of $1: 500$ for $48 \mathrm{~h}$ at $4^{\circ} \mathrm{C}$. After the sections had been rinsed, they were incubated with goat anti-rabbit IgG (AP132; Chemicon) at a dilution of $1: 100$, and then with rabbit PAP (PAP18; Chemicon) at a dilution of 1:400. After the sections had been rinsed with TBS, they were reacted with the diaminobenzidine (DAB)- $\mathrm{H}_{2} \mathrm{O}_{2}$ kit (SK-4100; Vector, Burlingame, CA) for $3 \mathrm{~min}$ at room temperature.

\section{Fluorescence-activated cell sorter (FACS) analysis}

Cultured E17.5 and P1 neurons were fixed after 10-14 DIV with $10 \%$ ethanol, incubated in $2 \mathrm{~N} \mathrm{HCl}$, and blocked with $10 \%$ goat serum plus $0.01 \%$ Triton 
$X-100$. The cells were incubated with primary antibodies (directed against MAP-2, BDNF, NGF, extracellular regulated kinase $1 / 2$ [ERK 1/2], phospho-ERK 1/2, p38, c-Jun N-terminal kinase 1/2 [JNK $1 / 2$ ], or phospho-JNK 1/2). After the cells had been washed, they were incubated with secondary antibody (FITC-conjugated anti-rabbit Ig; 1:200) for $2 \mathrm{~h}$. Fluorescence-positive cells were analyzed by flow cytometry (FACS Vantage, Becton Dickinson, San Jose, CA).

\section{Western blot analysis}

P1 neuronal cells (cerebral cortex, brainstem, and cerebellar regions) of wild-type and Gaucher mice were cultured for 10-14 DIV and used to analyze the MAPK pathway. Western blots were performed as described previously (Seo et al., 2004). Cells were homogenized with extraction buffer (10 mM PBS [pH 7.4], $0.5 \%$ sodium dodecyl sulfate [SDS], $10 \mathrm{mM}$ phenylmethylsulfonyl fluoride, and $10 \mu \mathrm{g} / \mathrm{ml}$ leu-
A
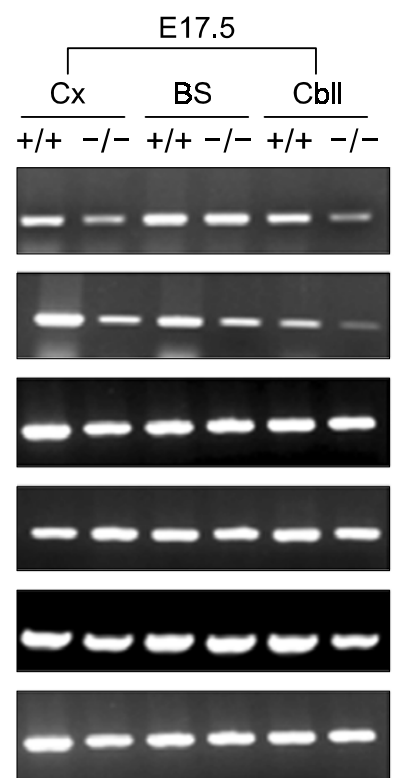
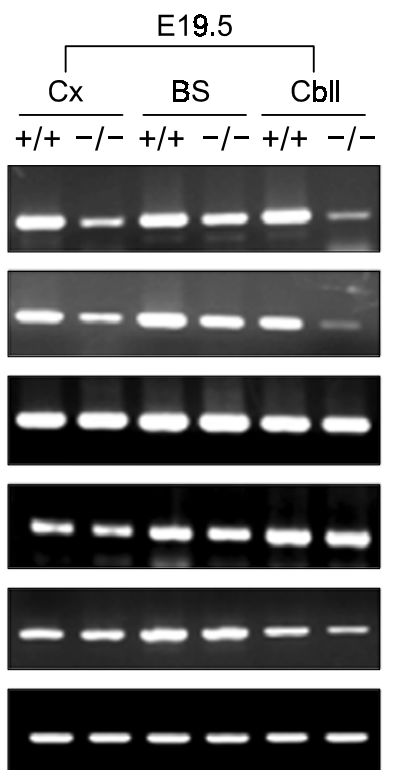
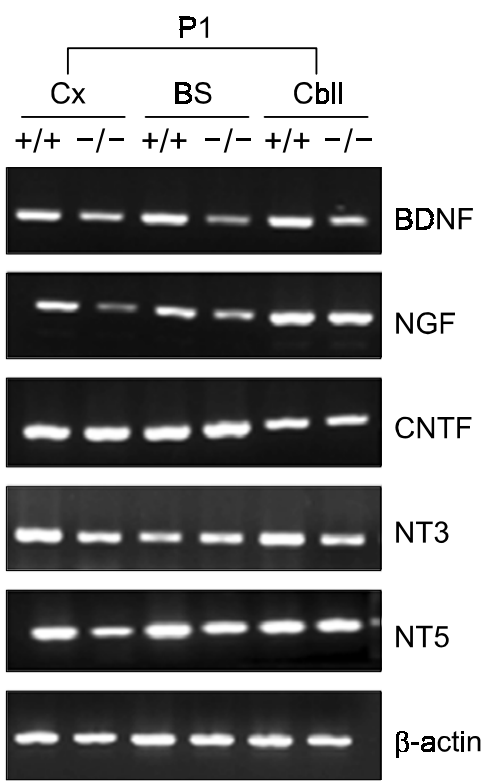

B

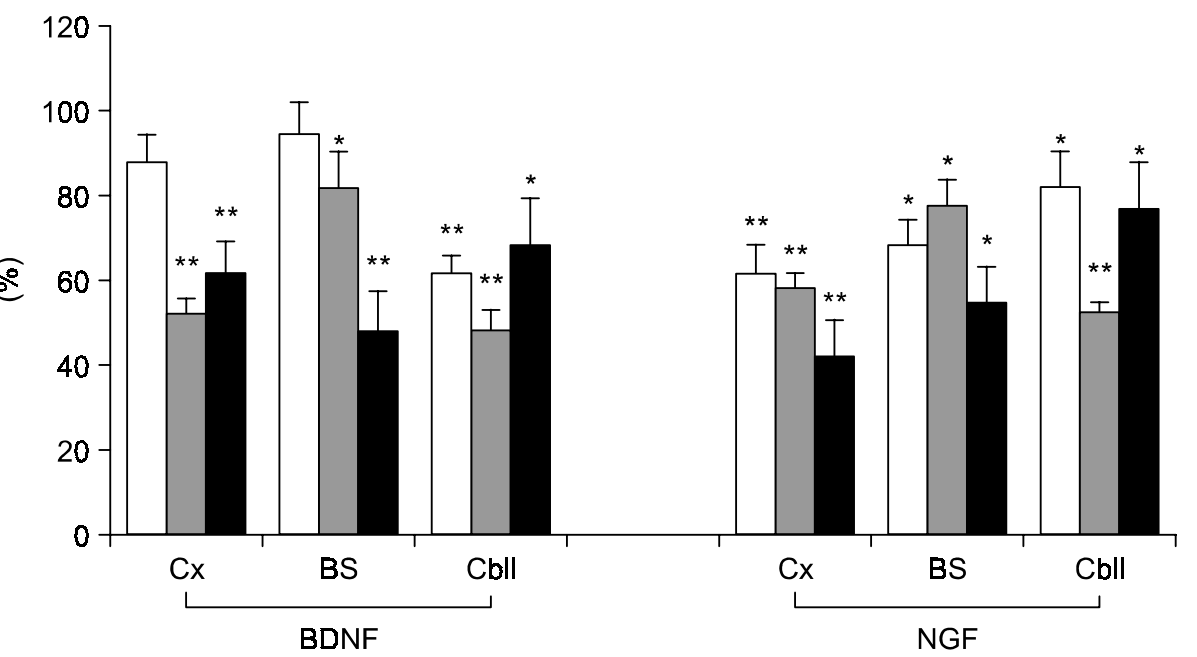

Figure 1. (A) RT-PCR analysis of the expression of the genes encoding neurotrophin family in the brains of wild-type mice and Gaucher mice at three developmental stages (E17.5, E19.5, and P1). Brains were dissected from wild-type mice and Gaucher mice and the cerebral cortex, brainstem, and cerebellar regions were separated. $\beta$-actin was used as the internal control. +/+, wild-type mice; -/-, Gaucher mice; Cx, cerebral cortex; BS, brainstem; Cbll, cerebellum. (B) Expression levels of BDNF and NGF proteins in the brains of wild-type and Gaucher mice at E17.5 and P1 were analyzed by FACS. white bar, E17.5; gray bar, E19.5; black bar, P1 mice. Data are expressed as means \pm SD $(n=3)$. *, $P<0.01$ and ${ }^{* *}, P<0.001$ versus corresponding wild-type mice using Student's $t$ test. 
peptin). The proteins were boiled for $5 \mathrm{~min}$, and 50 $\mu \mathrm{g}$ protein samples were separated by $9 \%$ SDSPAGE and blotted onto Hybond membrane (Amersham, Buckinghamshire, UK). The blots were probed with specific antibodies and then with the corresponding horseradish-peroxidase-conjugated secondary antibodies (Santa Cruz Biotechnology, Inc., Santa Cruz, CA). The proteins were visualized using enhanced chemiluminescence (ECL; Amersham, DE).

\section{Measurement of cell viability}

Live and dead cells were distinguished using $2 \mu \mathrm{M}$ calcein acetoxymethyl ester (calcein-AM) and $4 \mu \mathrm{M}$ ethidium homodimer 1 (EthD-1), respectively, as described in the Live/Dead Viability/Cytotoxicity Kit (Molecular Probes Inc., Eugene, OR). We compared survival under specific culture conditions at 1 DIV with survival under the same culture conditions at 10-14 DIV. Live cells were analyzed by flow cytometry (FACS Vantage).

\section{Statistical analysis}

Statistical analyses were performed using Student's $t$ test. Data are presented as means \pm SD.

\section{Results}

\section{Expression of neurotrophic factors in the brains of Gaucher mice}

To examine the roles of neurotrophic factors in Gaucher disease, we first investigated the expression of the genes for neurotrophic factors and their receptors in Gaucher mice. Expression of the mRNAs of the neurotrophin family (BDNF, NGF, neurotrophin 3 [NT3], and NT4/5), and of CNTF, GDNF, TGF- $\beta$, NGFR, and the tyrosine kinase receptor (Trk) family (TrkA, TrkB, and TrkC) was analyzed in the brains of wild-type and Gaucher mice at three developmental stages (E17.5, E19.5, and P1). Of the neurotrophic factors and the corresponding receptors that were analyzed, the expression of the genes encoding BDNF and NGF was reduced in Gaucher mice at all developmental stages (E17.5, E19.5, and P1) (Figure 1A). In the brains of Gaucher mice, low levels of BDNF expression were observed relative to those observed in wild-type mice in the cerebral cortex (88 $\pm 4 \%, 52$ $\pm 4 \%$, and $62 \pm 7 \%$; at E17.5, E19.5, and P1, respectively), brainstem (95 $\pm 2 \%, 82 \pm 8 \%$, and $48 \pm 9 \%$, respectively), and cerebellum (62 $\pm 5 \%$, $48 \pm 5 \%$, and $68 \pm 11 \%$, respectively). The expression of NGF was also lower in Gaucher mice

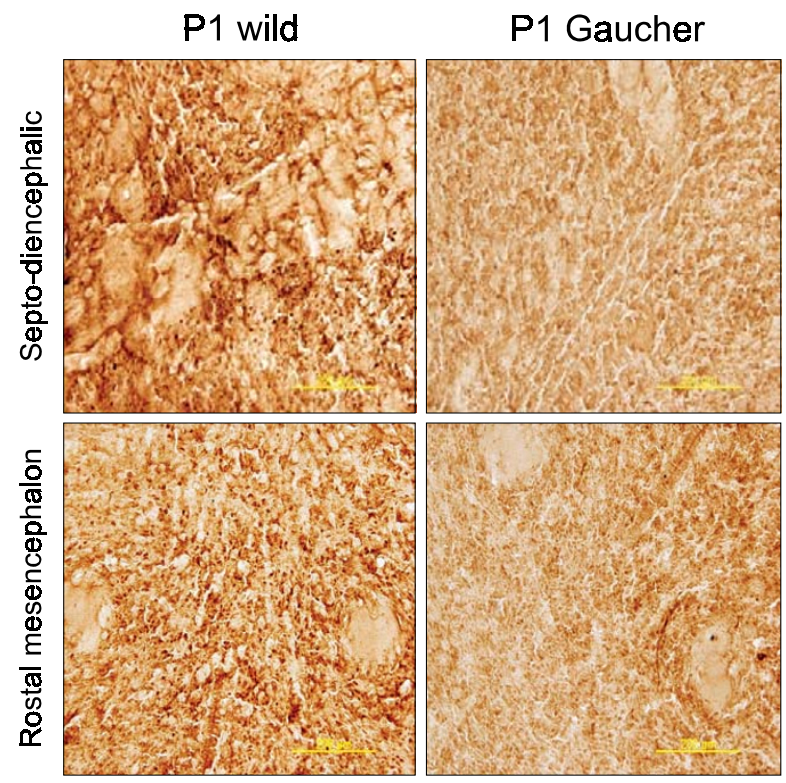

Figure 2. BDNF immunohistochemical staining of the septo-diencephalic region (upper panel) and rostral mesencephalon (lower panel) at $P 1$ in the brains of wild-type mice (left panel) and Gaucher mice (right panel). Cryosections $(40-50 \mu \mathrm{m})$ of whole brains were mounted on slides. Scale bar, $200 \mu \mathrm{m}$.

relative to that in wild-type mice in the cerebral cortex $(61 \pm 8 \%, 42 \pm 9 \%$, and $58 \pm 3 \%$; at E17.5, $E 19.5$, and $P 1$, respectively), brainstem (68 $\pm 5 \%$, $55 \pm 8 \%$, and $78 \pm 6 \%$, respectively), and cerebellum ( $82 \pm 6 \%, 77 \pm 11 \%$, and $52 \pm 3 \%$, respectively) (Figure 1B). In contrast, the expression levels of NT3, NT4/5, CNTF, GDNF, TGF- $\beta$, NGFR, and the Trk family were similar to those of wild-type mice at all stages of development. We then used immunohistochemistry to assess whether the decrease in BDNF mRNA correlated with a reduction in the expression of BDNF protein. BDNF protein was reduced in the septo-diencephalic region and the rostral mesencephalon in Gaucher mice at P1 (Figure 2).

\section{Expression levels of neurotrophic factors in cultured neurons from Gaucher mice}

Primary neurons from E17.5 and P1 mice were cultured for 10-14 DIV. Cultured neurons from Gaucher mice exhibited neuronal morphologies (axonal growth and branching, at $\mathrm{P} 1$, about $80 \%$ MAP-2 positive) similar to those of wild-type neurons (data not shown). Consistent with the results for brain tissue, RT-PCR indicated that the expression of BDNF and NGF transcripts was reduced in neuronal cultures (E17.5 and P1) (Figure 3A and B). The expression of the neurotrophic factors was 
A
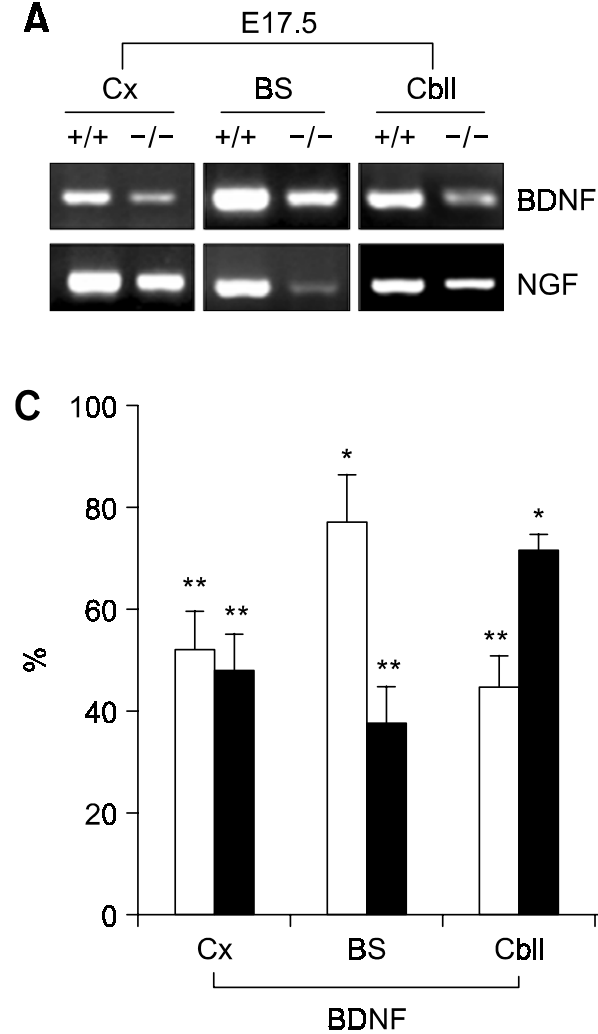

B

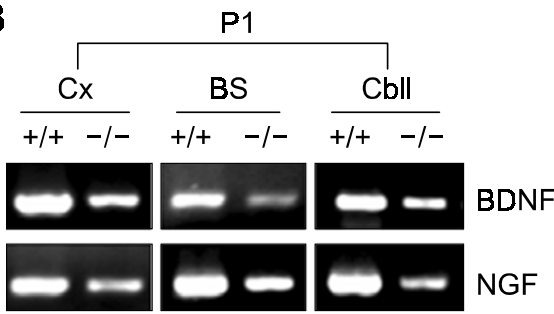

Figure 3. RT-PCR and FACS analysis of BDNF and NGF expression in cultured neurons. Brains of wild-type mice and Gaucher mice at E17.5 (A) and P1 (B) were separated into cerebral cortex, brainstem, and cerebellar regions, and the cells were then dissociated. RNA was extracted from neurons that had been maintained in Neurobasal ${ }^{\mathrm{TM}}$ medium and analyzed at 10-14 DIV. (C) Expression levels of BDNF and NGF proteins in cultured neurons at E17.5 (open bar) and P1 (closed bar) were analyzed by FACS. +/+, wild-type mouse neurons; ---, Gaucher mouse neurons; Cx, cerebral cortex; BS, brainstem; Cbll, cerebellum. Data are expressed as means $\pm S D(n=$ 3). *, $P<0.01$, and ${ }^{* *}, P<$ 0.001 versus corresponding wildtype neurons using Student's $t$ test.

quantified by FACS analysis (Figure 3C). BDNF and NGF expression was significantly reduced in cultured Gaucher mice neurons collected at P1 from the cerebral cortex $(48 \pm 8 \%$ and $45 \pm 7 \%$ of the levels observed in cultured wild-type neurons, respectively), brainstem ( $38 \pm 7 \%$ and $58 \pm 5 \%$ of the levels observed in cultured wild-type neurons, respectively), and cerebellum (72 $\pm 8 \%$ and $45 \pm$ $9 \%$ of the levels observed in cultured wild type neurons, respectively). In Gaucher mice at E17.5, the expression of BDNF and NGF was reduced in the cerebral cortex, brainstem, and cerebellum. The mean value of BDNF expression was 1.7-fold higher in neurons from wild-type mice $(100 \%)$ than that in neurons from Gaucher mice $(58.3 \pm 8 \%)$, and the level of NGF in neurons from wild-type mice was 1.8-fold higher than the level of NGF in neurons from Gaucher mice (54.6 $\pm 6 \%)$.

\section{Analysis of the MAPK pathway in neurons from Gaucher mice}

We then investigated whether this reduction in BDNF and NGF expression involved the MAPK pathway (ERK 1/2, p38, and JNK 1/2). Using immunoblotting (Figure 4A) and FACS analysis (Figure 4B), we found that ERK 1/2 phosphorylation was lower in the neurons of Gaucher mice than in those of wild-type mice. The expression of p38 and JNK was not significantly altered in Gaucher mice compared with that of wild-type mice (Figure 4C-F). Phosphorylation of ERK $1 / 2$ in the cerebral cortex, brainstem, and cerebellum of Gaucher mice at P1 was reduced to $65 \pm 8 \%, 80 \pm 11 \%$, and $45 \pm 7 \%$ of wild-type values, respectively. There was no difference in total ERK protein in cultured wild-type and Gaucher mouse neurons.

\section{Neuronal viability in vitro}

We measured the percentage of viable neurons present in each culture period. Most P1 wild-type neurons from the cerebral cortex, brainstem, and cerebellum remained viable after 1 DIV $(94 \pm 5 \%$, $83 \pm 7 \%$, and $76 \pm 9 \%$, respectively). However, the proportions of viable cells from the same brain regions of Gaucher mice were slightly reduced (71 $\pm 4 \%, 67 \pm 5 \%$, and $59 \pm 8 \%$, respectively). Cell viability was almost unchanged after 10-14 DIV in both wild-type mice (mean, $79 \pm 5 \%$ ) and Gaucher mice (mean, $61 \pm 8 \%$ ) compared with the level of viability observed after one day in culture for wild-type mice (mean, $84 \pm 7 \%$ ) and Gaucher mice (mean, $63 \pm 6 \%$ ). 
A

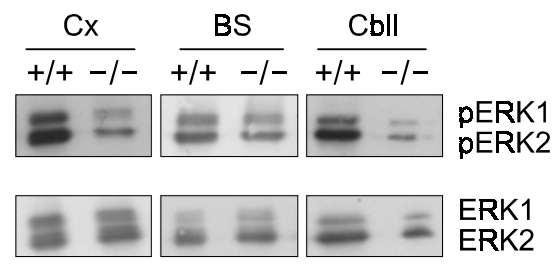

C

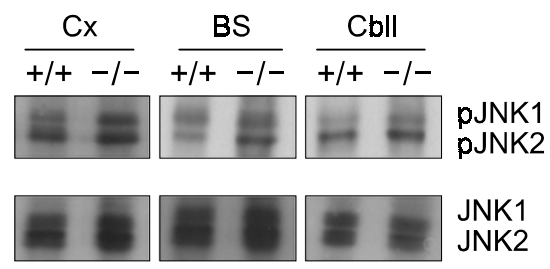

E

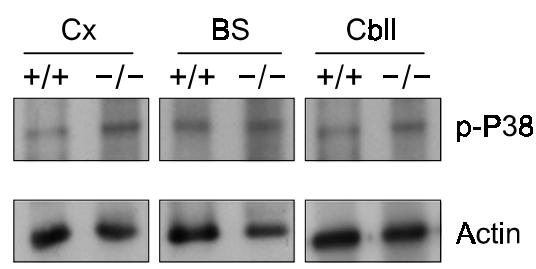

B
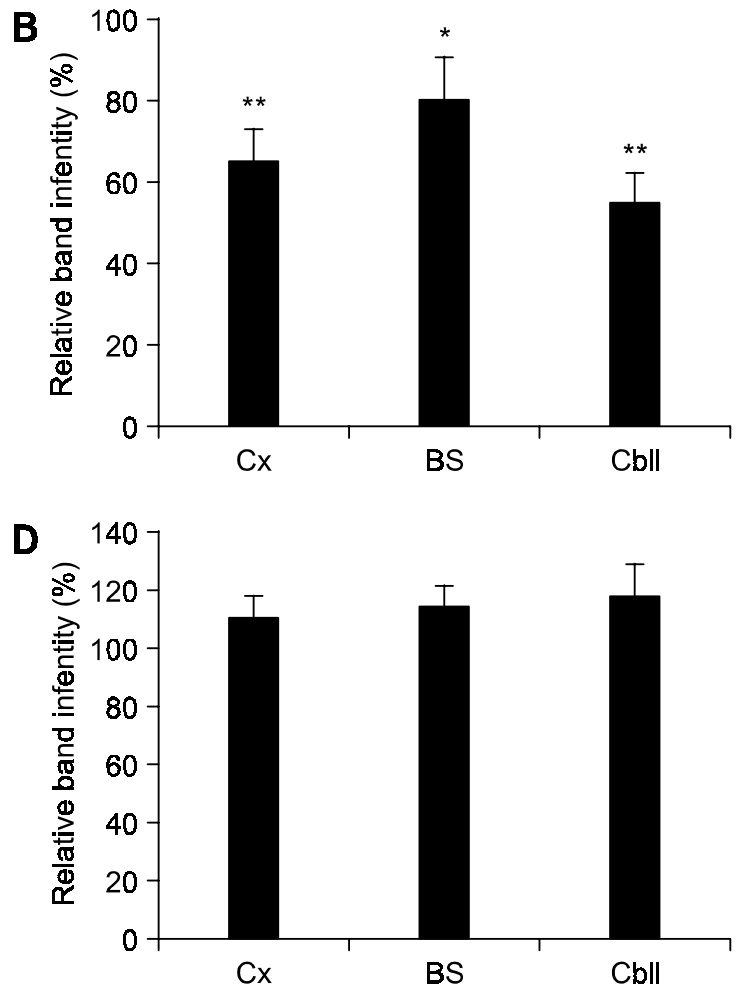

$\mathbf{F}$

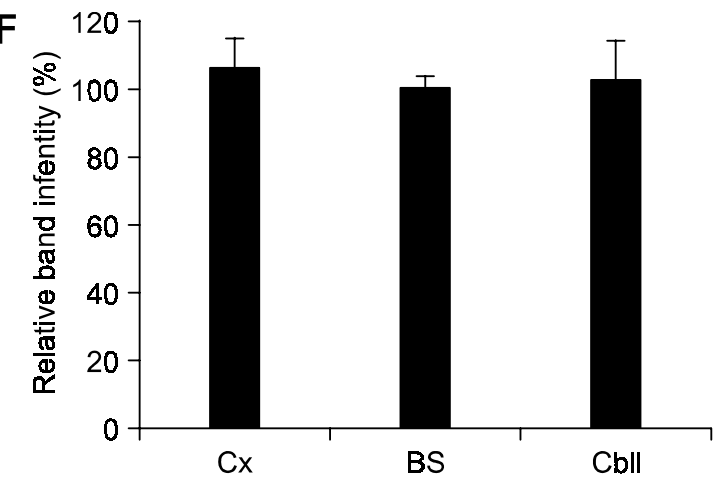

Figure 4. Western blot analysis of the MAPK pathway. Brains of wild-type mice and Gaucher mice at P1 were separated into cerebral cortex, brainstem, and cerebellar regions, and the cells were dissociated. Cell lysates from the P1 neuronal cells of wild-type and Gaucher mice from 10-14 DIV were immunoblotted with anti-phospho-ERK 1/2 and anti-ERK 1/2 antibodies (A), with anti- phospho-JNK $1 / 2$ and anti-JNK 1/2 antibodies (C), and with anti-phospho-P38 antibody (E). Levels of phospho-ERK 1/2 (B), phospho-JNK 1/2 (D), and phospho-P38 (F) were quantified by FACS. +/+, wild-type mouse neurons; -/-, Gaucher mouse neurons; $\mathrm{Cx}$, cerebral cortex; BS, brainstem; Cbll, cerebellum. Values shown are means $\pm \mathrm{SD}(n=3)$. ${ }^{*}, P<0.01$, and ${ }^{* *}, P<0.001$ versus corresponding wild-type neurons using Student's $t$ test.

\section{Discussion}

The brain pathology of neuronopathic forms of Gaucher disease is attributable to a deficiency in GC that leads to neuronal dysfunction (Brady et al., 1993). Type II patients show extensive damage in the brain, including gliosis in the dorsal brainstem and cochlear nuclei (Grafe et al., 1988; Kaga et al., 1998). It has recently been reported that the accu- mulation of glucosylceramide in cultured neurons can cause the release of $\mathrm{Ca}^{2+}$ from intracellular stores. These neurons are sensitive to neurotoxic agents that induce neuronal cell death and the accumulation of glucosylsphingosine, which contributes to neuronal destruction (Korkotian et al., 1999; Lloyd-Evans et al., 2003; Pelled et al., 2005). However, many questions remain unanswered regarding the pathogenesis of brain dysfunction in Gaucher 


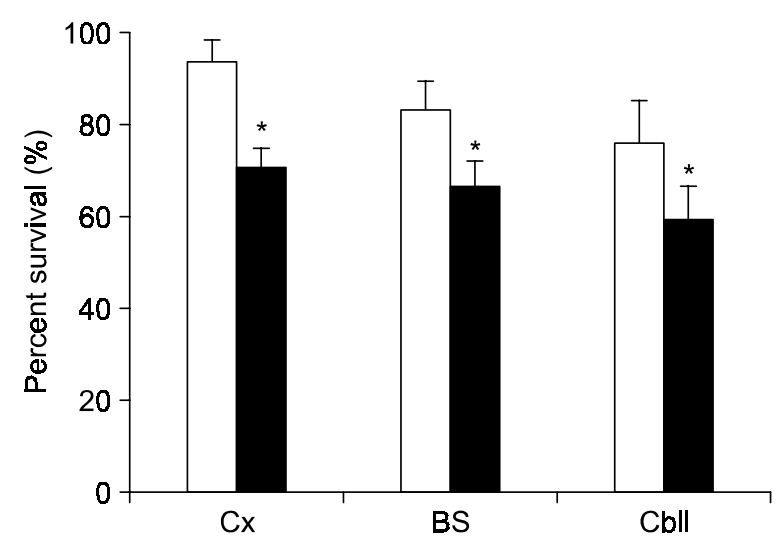

Figure 5. Cell viability assay on cultured neurons. P1 neurons from wild type and Gaucher mice were cultured in neurobasal medium for 14 days. Cells that survived were quantified using the Live/Dead Viability/Cytotoxicity assay. Open bar, wild type neuron; closed bar, Gaucher neuron; Cx, cerebral cortex; BS, brainstem; Cbll, cerebellum. Data are expressed as means $\pm \mathrm{SD}(n=3)$. ${ }^{*}, P<0.01$ versus corresponding wild type neurons using Student's $t$ test.

disease.

In this study, we found that the expression of genes for the neurotrophic factors BDNF and NGF is reduced in the cerebral cortex, brainstem, and cerebellum of the Gaucher mouse compared with that of the wild-type mouse at various developmental stages. Both neurotrophic factors were gradually downregulated by developmental stages, except in cerebellum. Among the regions in the brain of Gaucher mouse, there were no significant differences of the expression levels of neurotrophic factors. Similarly, a deficiency of neurotrophic factors was observed in cultured neurons (E17.5 and P1) from Gaucher mice. These results suggest that the accumulation of glucosylceramide or glucosylsphingosine affects the expression of the genes for BDNF and NGF in the brain. These results are consistent with those of previous studies, which found that BDNF and NGF can protect cultured cerebellar granule neurons against apoptosis (D'Arcangelo and Halegoua, 1993; Lindholm et al., 1993) and that trophic factor deprivation induces apoptosis in neurons (Dugan et al., 1995).

BDNF and NGF protect neurons, and these neurotrophic factors activate the MAPK pathway (Crowley et al., 1994; Nonomura et al., 1996; Dudek et al., 1997). The MAPK pathway comprises a family of signaling molecules that transduce extracellular stimuli into intracellular responses under a wide variety of circumstances. Neurotrophic factors activate the MAPK pathway in cerebellar granule cells and this activation mediates cell survival and cell growth (Zirrgiebel et al., 1995). The MAPK family includes ERK 1/2, p38, JNK, and ERK 5 (Widmann et al., 1999). The role of ERK in neuronal degeneration is unclear. However, the activation of ERK is typically associated with cell survival, cell proliferation, and cell differentiation, given that ERK is activated by mitogens and some cell survival factors (Xia et al., 1995; Li et al., 1998). Therefore, the reduced phosphorylation ratio of ERK $1 / 2$ that was observed in this study could have a negative effect on the survival of neurons in Gaucher mice. These results indicate that reductions in BDNF and NGF may be involved in causing neuronopathic forms of Gaucher disease, because neurotrophic factors are associated with neuronal survival during development.

However, it is unclear whether neurotrophic factors protect neurons or whether they are beneficial to neurons in Gaucher mice. In this study, the levels of the pro-neurotrophins, pro-BDNF and proNGF, were not quantified. Pro-neurotrophins induce apoptosis in neurons and glia (Lee et al., 2001; Beattie et al., 2002). The effects of reduced levels of BDNF and NGF on the expression of pro-neurotrophins in the brain of the Gaucher mouse should be clarified because apoptosis is a programmed event, possibly resulting from cellular dysfunction in another area. In vivo approaches to understanding the pathophysiology of Gaucher disease and the development of new therapeutic strategies to address it have previously been hindered by the lack of a viable animal model (Tybulewicz et al., 1992; Liu et al., 1998). However, the generation of viable mouse models of Gaucher disease has recently been reported (Xu et al., 2003; Sun et al., 2005), and these mouse models will be useful in elucidating the pathogenesis of Gaucher disease.

Further investigation of the relationship between the regulation of neurotrophic factors and the accumulations of GC substrates should clarify the role of neuronal death in Gaucher disease.

\section{Acknowledgment}

This work was supported by Korea Research Foundation Grant funded by Korea Government (MOEHRD, Basic Research Promotion Fund) (KRF2005-003-E00017).

\section{References}

Beattie MS, Harrington AW, Lee R, Kim JY, Boyce SL, Longo FM, Bresnahan JC, Hempstead BL, Yoon SO. ProNGF induces $\mathrm{p75}$-mediated death of oligodendrocytes following spinal cord injury. Neuron 2002;36:375-86

Beutler E, Grabowski GA. Gaucher disease. In The Metabolic and Molecular Bases of Inherited Disease (Scriver CR, 
Beaudet AL, Sly WS, Valle D, eds), 2001, 3635-668, McGraw-Hill, New York, NY

Brady RO, Barton NW, Grabowski GA. The role of neurogenetics in Gaucher disease. Arch Neurol 1993;50:1212-24

Brady RO, Kanfer JN, Shapiro D. Metabolism of glucocerebrosidase. II. Evidence of an enzymatic deficiency in Gaucher's disease. Biochem Biophys Res Commun 1965;18:221-5

Brady RO, Kanfer JN, Bradley RM, Shapiro D. Demonstration of a deficiency of glucocerebroside-cleaving enzyme in Gaucher's disease. J Clin Invest 1966;45:1112-5

Conradi NG, Sourander P, Nillsson O, Svennerholm L, Erikson A. Neuropathology of the Norrbottnian type of Gaucher disease. Morphological and biochemical studies. Acta Neuropathol 1984;65:99-109

Crowley C, Spencer SD, Nishimura MC, Chen KS, Pitts-Meek $S$, Armanini MP, Ling LH, MacMahon SB, Shelton DL, Levinson $A D$. Mice lacking nerve growth factor display perinatal loss of sensory and sympathetic neurons yet develop basal forebrain cholinergic neurons. Cell 1994;76:1001-11

D'Arcangelo G, Halegoua S. A branched signaling pathway for nerve growth factor is revealed by Src-, Ras-, and Raf-mediated gene inductions. Mol Cell Biol 1993;13:314655

Dudek H, Datta SR, Franke TF, Birnbaum MJ, Yao R, Cooper GM, Segal RA, Kaplan DR, Greenberg ME. Regulation of neuronal survival by the serine-threonine protein kinase Akt. Science 1997;275:661-5

Dugan LL, Sensi SL, Canzoniero LM, Handean SD, Rothman SM, Lin TS, Goldberg MP, Choi DW. Mitochondrial production of reactive oxygen species in cortical neurons following exposure to $N$-methyl-D-aspartate. J Neurosci 1995;15:637788

Ernfors P, Lee KF, Jaenisch R. Mice lacking brain-derived neurotrophic factor develop with sensory deficits. Nature 1994;368:147-50

Grafe M, Thomas C, Schneider J, Katz B, Wiley C. Infantile Gaucher's disease: a case with neuronal storage. Ann Neurol 1988;23:300-3

Heese K, Nagai Y, Sawada T. Nerve growth factor (NGF) induces mRNA expression of the new transcription factor protein p48ZnF. Exp Mol Med 2004;36:130-4

Hong YB, Kim EY, Jung SC. Down-regulation of Bcl-2 in the fetal brain of the Gaucher disease mouse model: a possible role in the neuronal loss. J Hum Genet 2004;49:349-54

Jones KR, Farinas I, Backus C, Reichardt IF. Targeted disruption of the BDNF gene perturbs brain and sensory neuron development but not motor neuron development. Cell 1994;76:989-99

Kaga K, Ono M, Yakumaru K, Owada N, Mizutani T. Brainstem pathology of infantile Gaucher's disease with only wave I and II of auditory brainstem response. J Laryngol Otol 1998;112:1069-73

Korkotian E, Schwarz A, Pelled D, Schwarzmann G, Segal $\mathrm{M}$, Futerman $\mathrm{AH}$. Elevation of intracellular glucosylceramide levels results in an increase in endoplasmic reticulum density and in functional calcium stores in cultured neurons. J Biol Chem 1999;274:21673-8

Lee R, Kermani P, Teng KK, Hempstead BL. Regulation of cell survival by secreted proneurotrophins. Science 2001; 294:1945-8

Letterio JJ. Murine models define the role of TGF- $\beta$ as a master regulator of immune cell function. Cytokine Growth Factor Rev 2000;11:81-7

Li YX, Zhang Y, Lester HA, Schuman EM, Davidson N. Enhancement of neurotransmitter release induced by brainderived neurotrophic factor in cultured hippocampal neurons. J Neurosci 1998;18:10231-40

Lindholm D, Dechant G, Heisenberg CP, Thoenen $H$. Brain-derived neurotrophic factor is a survival factor for cultured rat cerebellar granule neurons and protects them against glutamate-induced neurotoxicity. Eur J Neurosci 1993;5:1455-64

Liu Y, Suzuki K, Reed JD, Grinberg A, Westphal H, Hoffmann A, Doring T, Sandhoff K, Proia RL. Mice with type 2 and 3 Gaucher disease point mutations generated by a single insertion mutagenesis procedure (SIMP). Proc Natl Acad Sci USA 1998;95:2503-8

Lloyd-Evans E, Pelled D, Riebeling C, Bodennec J, deMorgan A, Waller H, Schiffmann R, Futerman AH. GlucosyIceramide and glucosylsphingosine modulate calcium mobilization from brain microsomes via different mechanisms. J Biol Chem 2003;278:23594-9

Miller TM, Tansey MG, Johnson EM Jr, Creedon DJ. Inhibition of phosphatidylinositol 3-kinase activity blocks depolarization- and insulin-like growth factor I-mediated survival of cerebellar granule cells. J Biol Chem 1997;272:9847-53

Nonomura T, Kubo T, Oka T, Shimoke K, Yamada M, Enokido $\mathrm{Y}$, Hatanaka $\mathrm{H}$. Signaling pathways and survival effects of BDNF and NT-3 on cultured cerebellar granule cells. Brain Res Dev Brain Res 1996;97:42-50

Orvisky E, Sidransky E, McKinney CE, Lamarca ME, Samimi R, Krasnewich D, Martin BM, Ginns El. Glucosylsphingosine accumulation in mice and patients with type 2 Gaucher disease begins early in gestation. Pediatr Res 2000;48:33-7

Pelled D, Trajkovic-Bodennec S, Lloyd-Evans E, Sidransky E, Schiffmann R, Futerman AH. Enhanced calcium release in the acute neuronopathic form of Gaucher disease. Neurobiol Dis 2005;18:83-8

Sendtner M, Schmalbruch H, Stockli KA, Carroll P, Kreutzberg GW, Thoenen $\mathrm{H}$. Ciliary neurotrophic factor prevents degeneration of motor neurons in mouse mutant progressive motor neuronopathy. Nature 1992;358:502-4

Seo HR, Kwan YW, Cho CK, Bae S, Lee SJ, Soh JW, Chung $\mathrm{HY}$, Lee YS. PKC $\alpha$ induces differentiation through ERK1/2 phosphorylation in mouse keratinocytes. Exp Mol Med 2004;36:292-9

Sternberger LA, Sternberger NH. The unlabeled antibody method: comparison of peroxidase-antiperoxidase with avidin-biotin complex by a new method of quantification. J Histochem Cytochem 1986;34:599-605 
Sun Y, Quinn B, Witte DP, Grabowski GA. Gaucher disease mouse models: point mutations at the acid $\beta$-glucosidase locus combined with low-level prosaposin expression lead to disease variants. J Lipid Res 2005;46:2102-13

Tybulewicz VLJ, Tremblay ML, LaMarca ME, Willemsen R, Stubblefield BK, Winfield S, Zablocka B, Sidransky E, Martin BM, Huang SP. Animal model of Gaucher disease from targeted disruption of the mouse glucocerebrosidase gene. Nature 1992;357:407-10

Widmann C, Gibson S, Jarpe MB, Johnson GL. Mitogen-activated protein kinase: conservation of a three-kinase module from yeast to human. Physiol Rev 1999;79:143-80

Wong K, Sidransky E, Verma A, Mixon T, Sandberg GD, Wakefield LK, Morrison A, Lwin A, Colegial C, Allman JM, Schiffmann R. Neuropathology provides clues to the pathophysiology of Gaucher disease. Mol Genet Metab 2004;
$82: 192-207$

Xia Y, Ragan RE, Seah EE, Michaelis ML, Michaelis EK. Developmental expression of $\mathrm{N}$-methyl-D-aspartate (NMDA)induced neurotoxicity, NMDA receptor function, and the NMDAR1 and glutamate-binding protein subunits in cerebellar granule cells in primary cultures. Neurochem Res 1995;20:617-29

Xu YH, Quinn B, Witte D, Grabowski GA. Viable mouse models of acid $\beta$-glucosidase deficiency: the defect in Gaucher disease. Am J Pathol 2003;163:2093-101

Zirrgiebel U, Ohga $Y$, Carter B, Berninger B, Inagaki N, Thoenen $H$, Lindholm $D$. Characterization of TrkB receptor-mediated signaling pathways in rat cerebellar granule neurons: involvement of protein kinase $C$ in neuronal survival. J Neurochem 1995;65:2241-50 